\title{
A Study of Discriminatory Practices in Rental Housing
}

\author{
ARALOYIN Funmilayo Moyinola and AYORINDE Olutayo Isaac \\ Obafemi Awolowo University, Ile-Ife, Osun State, Nigeria
}

\begin{abstract}
The responsibility for uncovering rental discrimination falls on researchers and all stakeholders in the rental sector. The study examined discriminatory practices in Nigerian rental housing with a view to providing information that could expose the existence of discrimination. Questionnaires were administered on 417 renters and data collected were analyzed using descriptive statistics and factor analysis. The study found disparate treatment of renters in the study area. Rental discriminatory practices found include "Landlord creating different terms or standards for certain tenants" which received a mean score of 3.9614; "I was told housing is not available for rental when it is, in fact, available" received a mean rating of 3.8410; "I was denied negotiation for a rental" (3.4892). The study also revealed that real estate agents discriminate, landlords and tenants also discriminate. Some rental discriminatory forms are subtle and this explain why rental discrimination has proved to be difficult to detect or eliminate. The study recommends for continued fair housing enforcement activities to ensure that all have equal opportunity to housing.
\end{abstract}

Keywords: Discrimination, rental housing, landlords, renters

DOI: $10.7176 / \mathrm{JEES} / 11-12-04$

Publication date: December $31^{\text {st }} 2021$

\section{Introduction}

Housing is usually the most expensive single purchase a family or an individual makes, and it often costs several times the annual household income. Due to the high cost, most individuals do not have the capacity to possess a house and this results in house rental from those who own more than one house or apartment. Booth (2006) and Oakes and McKee (1997) noted that despite owner occupation being viewed by the public as the preferred route to acquiring a house, renting was perceived as a popular choice for its ability to deliver freedom and flexibility, including the perception of renters that more disposable income would be available to purchase other priorities.

However, in the course of letting, many scholars have noted that renters are exposed to discrimination, that is, the unfair treatment of a person or group on the basis of prejudice or treatment of people differently by their differences. Discrimination has been defined as the act of making distinction in favour of or against a person". Hall (2005) noted that discrimination is a lot more than just that. It is hating, hurting, judging, ignorance, with a lot of negative consequences. The world we live in has been struggling with this sensitive subject, for as long as we have record of it. In all countries, there is most likely at least one kind of discrimination that affects people of different groups.

Past studies revealed that rental housing discrimination is a common phenomenon across the globe. It has been described by as one of the most intractable and virulent forms of discrimination. It occurs when rental of housing is denied to otherwise qualified individuals because of their ethnicity, race, marital status, gender, disability or religion. Discrimination in rental housing is often heightened when there is limited availability of affordable housing and long waiting lists. According to Marsden (1994), rental discrimination may be obvious or subtle, for example, when the landlord tells a person, in a friendly way, that the apartment is no longer available, and then rents it later to someone else. The renter may never know that rental discrimination has occurred. An individual's experience of discrimination in rental housing has far-reaching impacts and also affects friends, families, neighbours, communities and the society as a whole (Hall, 2005). According to Rosenberg (2005), several steps have been taken to combat rental housing discrimination. However, rental discrimination has not been eliminated by court actions.

This paper therefore investigated discriminatory practices in the Nigerian rental housing sector with a view to providing information that will help stakeholders to detect rental housing discrimination.

\section{Review of Literature}

Discrimination takes the form of different information about the number of potential housing available for rental, information about asking prices, privileges, facilities and financing being provided to prospective renters or buyers of different races. Beatty and Sommervoll (2008) considered the rental market as a more fertile ground for the study of discrimination. According to the authors, the relationship between a tenant and a landlord can be lengthy and a good match benefit both parties. However, both tenant and landlord have different objectives and faces different risk. The tenant faces potential risks regarding attributes of the dwelling that may not be readily observable on first inspection. The landlord faces a complex mix of risks: How long will they stay? Will the tenant pay on time? How many tenants will reside in the property? Will the tenant take good care of the dwelling? A 
potential result of this signaling game is a rental contract.

The study by Beatty and Sommervoll (2008) found that tenants born abroad pay a statistically significant and economically important premium for their dwelling units. The authors found that price discrimination is consistent with profit maximizing behaviour. This finding may help to explain why rental discrimination has proved to be difficult to eliminate. The results of a study by Ondrich, Ross and Yinger (2001) in US demonstrated that illegal discrimination in housing sales/rents grows out of profit-maximizing behaviour by real estate surveyors.

Choi et al. (2005) considered an updated sample of renters and found that while discrimination has declined relative to earlier studies, it is still present. This kind of disparate treatment according to the authors yields higher costs of information resulting in higher housing or rental costs. According to Zalesne (1997), landlords typically have significant power over their tenants, including the power to set the rent, to decide who is qualify to rent their apartment, to evict a tenant, to provide or withhold certain privileges or services. Landlords have additional power because of the historical allocation of property in American society and widespread shortages of adequate rental housing in urban areas. The housing crisis in a nation's cities most seriously affects low-income earners. As a result of this, poor tenants are often in subordinate positions with respect to their landlords.

Ahmed and Hammarstedt (2007) studied gender and ethnic discrimination in the rental housing market in Sweden with the help of a field experiment on the internet by letting three testers, one with a typical male Swedish name, one with a typical female Swedish name, and one with a typical male Arabic/Muslim name applied for vacant rental apartments advertised by landlords on the internet. Their results showed that the Arabic/Muslim male got far fewer call backs, inquires and showings for each application that was sent out. Their observations also indicate that women meet with less difficulties in finding an apartment than men. Thus, they concluded that ethnic as well as gender discrimination occurs in the housing market.

Yinger (1986) studied Fair Housing Audits in the Boston housing market (US), and found disparate treatment of minorities in both rental and sales audits. Yinger concluded that the primary cause of this discrimination was that housing agents prejudice against blacks and cater to current or potential white customers. Bosch, Carnero and Farre (2009) investigated the effect of disclosing information on the discriminatory behaviour against immigrants in the Spanish rental market. Their results showed that applicants with a Moroccan sounding name are 15 percentage points less likely to be contacted by the property owner than those with a Spanish name.

A study by Hulchanski (2004) revealed that landlords use minimum or maximum income as criteria for evaluating prospective tenants in the rental housing sector. This is subject to a great deal of controversy and even to the extent of serious claims, it is a discriminatory practice. The author was of the opinion that the use of income criteria is not a valid measuring instrument in rental housing market. It is rare to find a consumer good or service in which the producer/supplier first applies an income test to determine affordability for the purposes of refusing to sell to the prospective customer if they fail the affordability test. For most producer/supplier it is sufficient to have a prospective customer present the required amount of money for the good or service.

A study by the Ontario Human Rights Commission (1993) estimated that about eighty percent of the housing complaints are connected to the use of minimum income criteria. Does having a lower than average level of income make a prospective tenant more or less reliable in terms of paying rent than someone with a higher than average level of income? Is a lower than average level of income a reliable and valid requirement of a prospective tenant's ability to pay? Is a lower than average level of income a reliable and valid requirement of a prospective tenant willingness to pay?

Roychoudry and Goodman (1996) examine differences in units shown to auditors in the Detroit area, keeping track of real estate agents' characteristics. The study confirmed racial discrimination, that blacks were shown significantly fewer units, and that this discrimination is less common among black agents and more common among older agents, illustrating that dimension other than auditor heterogeneity may play an important role in explaining discrimination. Yinger (1998) and Dymski (2001) also provided overview of discrimination in housing markets. The studies revealed that neigbourhood characteristics play important role in housing discrimination. Their findings showed that discrimination was quite different in different neighbourhoods and they found a link between discrimination and the racial composition of a neighbourhood.

Galster (1990) reviewed the results of 71 housing audits carried out by local housing authorities during the 1980s in the United States. The total number of audit studies available to calculate the rate of discrimination against blacks in housing availability is unfortunately lower. A number of the audit studies focus on discrimination against Hispanics and so are not applicable. Furthermore, many of the written reports that Galster received in response to his survey were incomplete. However Galster found that the incidence of housing discrimination against blacks is 47 percent in rental housing and 21 percent in owner-occupied housing markets.

All these studies revealed the existence of discrimination in the rental housing market. Landlords/real estate agents often reject tenants on discriminatory reasons. These discriminatory practices continue to create serious problem to the welfare and development of our society, hence the need for appropriate measures to offset their effects. This study however sets out to establish the types of discrimination in the Nigerian rental housing market. The study also brings to public attention a phenomenon that is not very visible but comes with a great cost for 
society.

\section{Research method}

This study adopted self-administered questionnaires on the respondents. The respondents consist of renters residing in the study area. 417 renters were surveyed using simple random sampling technique. Data collected were analysed using mean rating and factor analysis.

Table 1.0

Sample Characteristics for Renters

\section{Tenants (417)}

\begin{tabular}{|c|c|c|c|}
\hline Sex & $\begin{array}{l}\text { Male } \\
\text { Female }\end{array}$ & $\begin{array}{l}235 \\
182\end{array}$ & $\begin{array}{l}56.4 \% \\
43.6 \%\end{array}$ \\
\hline Age & $\begin{array}{l}<35 \\
36-50 \\
>50\end{array}$ & $\begin{array}{l}299 \\
92 \\
26\end{array}$ & $\begin{array}{c}71.7 \% \\
22.1 \% \\
6.2 \%\end{array}$ \\
\hline Marital Status & $\begin{array}{l}\text { Married } \\
\text { Single } \\
\text { Divorced } \\
\text { Widowed }\end{array}$ & $\begin{array}{l}196 \\
220 \\
0 \\
1\end{array}$ & $\begin{array}{l}47.0 \% \\
52.8 \% \\
0.0 \% \\
0.24 \%\end{array}$ \\
\hline Education & $\begin{array}{l}\text { Primary Sch. Certificate } \\
\text { Secondary Sch. Certificate } \\
\text { Diploma } \\
\text { Graduate Degree } \\
\text { Masters Degree } \\
\text { Others }\end{array}$ & $\begin{array}{l}17 \\
148 \\
8 \\
188 \\
46 \\
10\end{array}$ & $\begin{array}{l}4.1 \% \\
35.5 \% \\
1.9 \% \\
45.1 \% \\
11.0 \% \\
2.4 \%\end{array}$ \\
\hline Ethnic Group of Tenant & $\begin{array}{l}\text { Yoruba } \\
\text { Ibo } \\
\text { Hausa } \\
\text { Others }\end{array}$ & $\begin{array}{l}286 \\
115 \\
15 \\
1\end{array}$ & $\begin{array}{l}68.6 \% \\
27.6 \% \\
3.6 \% \\
0.24 \%\end{array}$ \\
\hline $\begin{array}{l}\text { Ethnic Group of their } \\
\text { Landlord }\end{array}$ & $\begin{array}{l}\text { Yoruba } \\
\text { Igbo } \\
\text { Hausa } \\
\text { Others }\end{array}$ & $\begin{array}{l}328 \\
81 \\
8 \\
0\end{array}$ & $\begin{array}{l}78.7 \% \\
19.4 \% \\
1.9 \% \\
0.0 \%\end{array}$ \\
\hline Religion & $\begin{array}{l}\text { Christianity } \\
\text { Islam } \\
\text { Traditional Worshipper } \\
\text { Others }\end{array}$ & $\begin{array}{l}305 \\
98 \\
1 \\
13\end{array}$ & $\begin{array}{l}73.1 \% \\
23.5 \% \\
0.24 \% \\
3.12 \%\end{array}$ \\
\hline Occupation & $\begin{array}{l}\text { Civil Servant } \\
\text { Self Employed } \\
\text { Others }\end{array}$ & $\begin{array}{l}147 \\
172 \\
98\end{array}$ & $\begin{array}{l}35.3 \% \\
41.2 \% \\
23.5 \%\end{array}$ \\
\hline Annual Income & $\begin{array}{l}<\mathrm{N} 500,000 \\
\mathrm{~N} 500,001-\mathrm{N} 1,000,000 \\
\mathrm{~N} 1,000,001-\mathrm{N} 1,500,000 \\
>\mathrm{N} 1,500,000\end{array}$ & $\begin{array}{l}287 \\
94 \\
22 \\
14\end{array}$ & $\begin{array}{l}68.8 \% \\
22.5 \% \\
5.3 \% \\
3.4 \%\end{array}$ \\
\hline
\end{tabular}

Table 1 presented the summary of the status of the study population which comprises renters in the study area. At a glance, the statistics revealed that these are people knowledgeable in the study under consideration with reasonable years of experience. Their ethnic groups cut across the three (3) major ethnic groups in Nigeria $(68.6 \%$ Yoruba; 27.6\% Igbo; 1.9\% Hausa). The two (2) basic religion (Christianity and Muslim) are well represented in 
the sample (73.1\% Christianity; 23.5\% Islam). A larger percentage of the samples are also literate with $58.5 \%$ holding a Graduate degree. The sample is well distributed between male and female (43.6\% Female; $56.4 \%$ Male). Therefore, the information obtained clearly represents the status of Nigerian renters and can be relied upon.

\section{Results and Discussion}

The types of rental discrimination were examined using descriptive statistics. Tables 2.0 showed the responses of renters on rental discrimination practices in the study area, their mean rating on a scale of 1 to 5 (strongly disagree to strongly agree).

Table 2.0 Types of Discrimination Experienced by Renters

\begin{tabular}{|c|c|c|c|c|}
\hline \multicolumn{5}{|l|}{ Descriptive Statistics } \\
\hline Discriminatory Practices & Mean & $\begin{array}{c}\text { Std. } \\
\text { Deviation }\end{array}$ & Rank & $\begin{array}{l}\text { Analysis } \\
\mathrm{N}\end{array}$ \\
\hline I was denied negotiation for a rental & 3.4892 & 1.46695 & 20 & 417 \\
\hline I was told housing is not available for rental when it was, in fact, available & 3.8410 & 1.42908 & 9 & 417 \\
\hline I was provided with inferior housing terms, privileges, facilities, or services & 3.9446 & 1.45937 & 4 & 417 \\
\hline I was harassed in connection with housing accommodations. & 3.3819 & 1.49558 & 21 & 417 \\
\hline I was refused to make reasonable modifications to a rental unit. & 3.8193 & 1.47724 & 10 & 417 \\
\hline My rental agreement was cancelled or terminated. & 3.1349 & 1.45400 & 26 & 417 \\
\hline I was refused to make reasonable accommodation in rules or services. & 3.6048 & 1.38417 & 24 & 417 \\
\hline I rented a property on worse terms than other tenants. & 3.0178 & 1.33425 & 27 & 417 \\
\hline I experienced different treatment compared to other tenants. & 3.2663 & 1.44290 & 25 & 417 \\
\hline Landlord making it difficult for the tenant to access electricity or water & 3.8072 & 1.36252 & 13 & 417 \\
\hline Landlord restricting tenant's access to some facilities. & 3.9012 & 1.35396 & 6 & 417 \\
\hline Landlord visiting the rented apartment without prior notice. & 3.8169 & 1.39364 & 11 & 417 \\
\hline Landlord visiting the rented apartment at inconvenient times. & 3.7422 & 1.38785 & 17 & 417 \\
\hline Landlord interfering with tenant's mails. & 3.0530 & 1.35920 & 28 & 417 \\
\hline $\begin{array}{l}\text { Organizing for workmen to arrive at the rented property without notifying } \\
\text { tenants. }\end{array}$ & 3.3819 & 1.41081 & 21 & 417 \\
\hline Entering the rented property without seeking tenant's permission. & 3.8747 & 1.38617 & 8 & 417 \\
\hline Landlord not carrying out the required repair works. & 4.1349 & 1.39048 & 1 & 417 \\
\hline Landlord leaving the property in a dangerous condition. & 3.9566 & 1.31438 & 3 & 417 \\
\hline Making it difficult or not denying a tenant from having visitors. & 3.8120 & 1.36674 & 12 & 417 \\
\hline $\begin{array}{l}\text { Carrying out action with the intention of causing disruption and nuisance to } \\
\text { the existing tenant. }\end{array}$ & 3.2759 & 1.31634 & 24 & 417 \\
\hline Preventing the tenant having a & 3.7518 & 1.35974 & 15 & 417 \\
\hline
\end{tabular}




\begin{tabular}{|l|r|r|r|r|}
\hline $\begin{array}{l}\text { Requiring tenants to sign agreements that could take away their legal } \\
\text { privileges or rights }\end{array}$ & 3.2823 & 1.39481 & 23 & 417 \\
\hline $\begin{array}{l}\text { Landlord creating unreasonable restrictions on the number of people that } \\
\text { may live in a rental unit }\end{array}$ & 3.7807 & 1.33428 & 14 & 417 \\
\hline Landlord making preferences or limitations in a rental advertisement & 3.7446 & 1.35037 & 16 & 417 \\
\hline Landlord creating different terms or standards for certain tenants & 3.9614 & 1.36324 & 2 & 417 \\
\hline Termination of tenancy based on a discriminatory reason. & 3.6229 & 1.38760 & 18 & 417 \\
\hline Provision of services or facilities only for certain tenants. & 3.8916 & 1.43466 & 7 & 417 \\
\hline $\begin{array}{l}\text { Landlord demanding for sexual favors or creating a sexually hostile } \\
\text { environment. }\end{array}$ & 3.9277 & 1.47592 & 5 & 417 \\
\hline $\begin{array}{l}\text { Refusal to make reasonable accommodations adjustment for a disabled } \\
\text { tenant. }\end{array}$ & 3.5084 & 1.39332 & 19 & 417 \\
\hline $\begin{array}{l}\text { Failure to stop another tenant from making threatening, harassing or } \\
\text { discriminatory comments to others. }\end{array}$ & 2.9386 & 1.23181 & 30 & 417 \\
\hline
\end{tabular}

The most significant type of rental discrimination according to renters is "Landlord not carrying out the required repair work". This response received a mean rating of 4.1349. Landlords are responsible for most repairs to the exterior or structure of a property; large repairs such as replacing a roof, problems with walls, fixing of doors, and rewiring electric are the responsibilities of the landlord. The study found this as a discriminatory rental practice in the study area. Next to this is "Landlord creating different terms or standards for certain tenants" which received a mean score of 3.9614. A landlord may require a tenant to pay a security deposit as a condition of entering into a tenancy agreement and wave it for other tenants. The study also found that some landlords restrict certain tenants from keeping pets on the residential property and allow others. However, this was followed at an insignificantly small distance by "Landlord leaving the property in a dangerous condition". This practice received a mean rating of 3.9566. A "dangerous condition" is condition of property that creates a substantial risk to the occupants of the building or members of the public. A dangerous condition may also refer to a condition in which the owner fails to exercise reasonable care in the use of the property.

"I was denied negotiation for a rental" received a mean rating of 3.4892. Negotiation is a strategic discussion that resolves an issue in a way that both parties find acceptable. In a situation where a landlord does not want a particular tenant, he/she will deny the tenant negotiation for a rental. "I was told housing is not available for rental when it is, in fact, available" received a mean rating of 3.8410. The study discovered that on some occasions the landlord will say to a person that an apartment is rented but continuing to show it to other applicants. There are cases where the signboard reads "Vacancy" but landlord says "It is rented." In other cases, the information the prospective tenant received on phone is different from the information he/she was told in person.

Another discriminatory practice that was investigated was "Entering the rented property without seeking tenant's permission". A renter does have a right to use enjoy the premises and the landlord cannot interfere unreasonably with that right by frequently entering the property or failing to give notice of entry. This practice was rated 3.8747 on a likert scale of 5. "My rental agreement was cancelled or terminated" was rated 3.1349 on a likert scale of 5. A major cause of rental termination in literature is tenant subleasing the property. In cases where the tenant's rental agreement was cancelled or terminated for no just reason, this is rental discrimination. The study also investigated into the practice of "Landlord creating unreasonable restrictions on the number of people that may live in a rental unit". Some landlords discriminate against families by setting unreasonably low occupancy limits. Landlords can be restrictive on the number of occupants in an apartment only in rare instances for health and safety reasons or other legitimate reasons such as limitations of the plumbing system or some other aspect of the building's infrastructure.

Landlord demanding for sexual favors or creates a sexually hostile environ was also investigated into. Unwelcome sexual advances, requests for sexual acts, and other verbal or physical conduct of a sexual nature constitute sexual harassment. A landlord creates a hostile living environment for a tenant through sexually offensive comments or touching. According to Steward (2009), it is illegal to refuse to rent to a person who resists the landlord's sexual advances or to make life difficult for a tenant who has resisted such advances. "Provision of 
services or facilities only for certain tenants" was rated 3.8916 on a likert scale of 5 . The lease agreement often states something specific that the tenant must or cannot do (like mow the yard or sublease to other parties). One of the remedy a landlord can use on a tenant who has broken the lease is having the tenant's facilities shut off or disconnected. The option "Refusal to make reasonable accommodation for a disabled tenant" was rated 3.5084 on a likert scale of 5. A disabled tenant has the right to modify his living space, at the tenant's expense, to the extent necessary to make the space safe and comfortable (Disability Act, 1995). I was refused permission to make reasonable modifications to a rental unit. Some landlords refuse tenants from putting nails on the walls, claiming that the nails may weaken the walls which could lead to building collapse on the long run.

Inquiries about "Requiring tenants to sign agreements which take away their legal rights" was rated 3.2823 on a likert scale of 5 . The study found that some clauses in the tenancy agreement attempt to limit or exclude some legal rights which tenants would otherwise have had. For example, a clause which stated that a tenant may only do something with the landlord's written consent, this should be followed by the words "(consent not to be unreasonably withheld)". The least significant type of discrimination according to renters is "Failure to stop another tenant from making discriminatory, harassing, or threatening comments to a person in a protected category". Disputes between tenants in neighboring apartments can be very difficult to deal with.

The study also found some other discriminatory practices in the study area such as landlord changing the locks to a rented apartment, shutting off access to certain facilities, seizing tenant's property for nonpayment of rent or any other reason, landlord using falsified reason for eviction etc.

KMO and Bartlett's Test for Rental Discrimination

\begin{tabular}{|c|c|c|}
\hline Kaiser-Meyer-Olkin Measur & $\begin{array}{l}\text { equacy. } \\
\text { Approx. Chi-Square }\end{array}$ & $\begin{array}{r}.946 \\
9873.911\end{array}$ \\
\hline Bartlett's Test of Sphericity & $\mathrm{Df}$ & 435 \\
\hline & Sig. & .000 \\
\hline
\end{tabular}

The factor analysis identified the underlying factors that explain the pattern of correlations within the set of observed variables. The justification for the factor analysis is the highly correlated Cronbach alpha inter-item correlation values. The rotated component matrix showing the factor loadings are shown in Table 3.0.

Table 3.0: Rental Discrimination

\begin{tabular}{|c|c|c|c|c|c|}
\hline \multicolumn{5}{|l|}{ Rotated Component Matrix ${ }^{a}$} & \multirow[t]{3}{*}{ Group } \\
\hline \multirow[t]{2}{*}{ Items } & \multicolumn{4}{|c|}{ Component } & \\
\hline & 1 & 2 & 3 & 4 & \\
\hline I was denied negotiation for a rental & .093 & .133 & .387 & .702 & 4 \\
\hline I was told housing is not available for rental when it was, in fact, available & .681 & .096 & .487 & .105 & 1 \\
\hline I was provided with inferior housing terms, privileges, facilities, or services & .163 & .323 & .375 & .654 & 4 \\
\hline I was harassed in connection with housing accommodations. & .427 & .406 & .068 & .562 & 4 \\
\hline I was refused to make reasonable modifications to a rental unit. & .468 & .318 & .594 & .090 & 3 \\
\hline My rental agreement was cancelled or terminated. & .092 & .158 & .629 & .556 & 3 \\
\hline I was refused to make reasonable accommodation in rules or services. & .455 & .271 & .629 & .147 & 3 \\
\hline I rented a property on worse terms than other tenants. & .414 & .397 & .182 & .400 & 1 \\
\hline I experienced different treatment compared to other tenants. & -.052 & .240 & .637 & .349 & 3 \\
\hline Landlord making it difficult for the tenant to access water or electricity & .501 & .554 & .297 & .266 & 2 \\
\hline Landlord restricting tenant's access to some facilities. & .376 & .685 & .671 & .191 & 2 \\
\hline Landlord visiting the rented apartment without prior notice. & .734 & .740 & .257 & .147 & 2 \\
\hline Landlord visiting the rented apartment at inconvenient times. & .727 & .728 & .227 & .188 & 2 \\
\hline
\end{tabular}




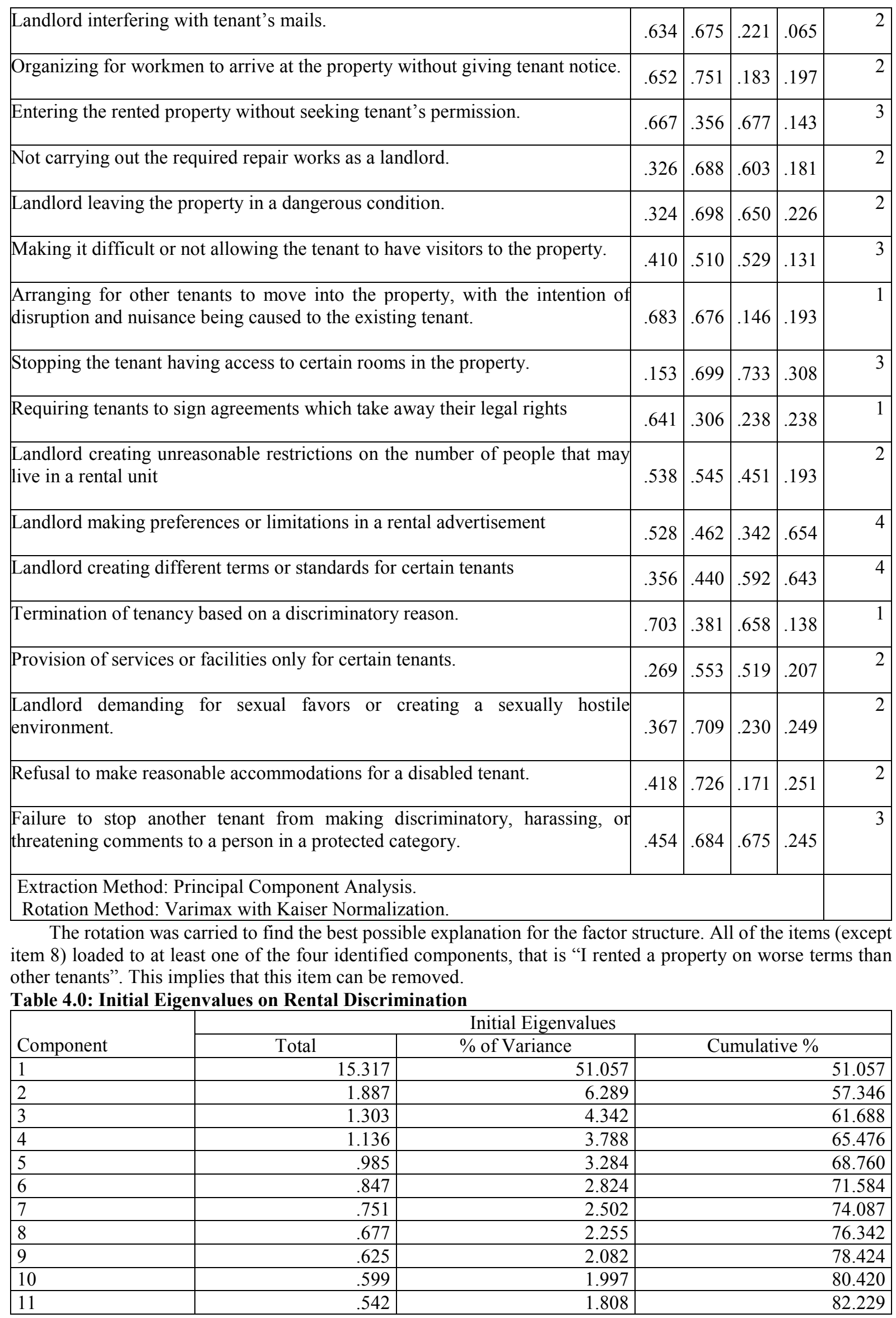




\begin{tabular}{|l|r|r|r|}
\hline 12 & .492 & 1.639 & 83.868 \\
\hline 13 & .466 & 1.554 & 85.421 \\
\hline 14 & .430 & 1.433 & 86.855 \\
\hline 15 & .400 & 1.333 & 88.188 \\
\hline 16 & .365 & 1.216 & 89.404 \\
\hline 17 & .357 & 1.191 & 90.595 \\
\hline 18 & .325 & 1.083 & 91.678 \\
\hline 19 & .311 & 1.036 & 92.714 \\
\hline 20 & .303 & 1.009 & 93.723 \\
\hline 21 & .265 & .882 & 94.605 \\
\hline 22 & .242 & .806 & 95.411 \\
\hline 23 & .220 & .733 & 96.144 \\
\hline 24 & .210 & .701 & 96.845 \\
\hline 25 & .197 & .656 & 97.501 \\
\hline 26 & .184 & .613 & 98.114 \\
\hline 27 & .179 & .595 & 98.709 \\
\hline 28 & .144 & .481 & 99.190 \\
\hline 29 & .138 & .460 & 99.650 \\
\hline 30 & .105 & .350 & 100.000 \\
\hline
\end{tabular}

Eigenvalues are calculated and used in deciding how many factors to extract in the overall factor analysis. The first four components explain $65.476 \%$ of the variance observed in the data.

Table 5.0: Total Variance Explained

\begin{tabular}{|l|r|r|r|r|r|r|r|r|r|}
\hline \multicolumn{9}{|c|}{ Total Variance Explained } \\
\hline \multirow{2}{*}{$\begin{array}{l}\text { Pon- } \\
\end{array}$} & \multicolumn{3}{|c|}{ Initial Eigenvalues } & \multicolumn{2}{|c|}{$\begin{array}{c}\text { Extraction Sums of Squared } \\
\text { Loadings }\end{array}$} & \multicolumn{3}{|c|}{$\begin{array}{c}\text { Rotation Sums of Squared } \\
\text { Loadings }\end{array}$} \\
\cline { 2 - 11 } & Total & $\begin{array}{c}\text { \% of } \\
\text { Variance }\end{array}$ & $\begin{array}{c}\text { Cumula- } \\
\text { tive \% }\end{array}$ & Total & $\begin{array}{c}\text { \% of } \\
\text { Variance }\end{array}$ & Cumulative \% & Total & $\begin{array}{c}\text { \% of } \\
\text { Variance }\end{array}$ & Cumulative \% \\
\hline 1 & 15.317 & 51.057 & 51.057 & 15.317 & 51.057 & 51.057 & 6.135 & 20.448 & 20.448 \\
\hline 2 & 1.887 & 6.289 & 57.346 & 1.887 & 6.289 & 57.346 & 5.048 & 16.827 & 37.275 \\
\hline 3 & 1.303 & 4.342 & 61.688 & 1.303 & 4.342 & 61.688 & 4.577 & 15.256 & 52.531 \\
\hline 4 & 1.136 & 3.788 & 65.476 & 1.136 & 3.788 & 65.476 & 3.884 & 12.946 & 65.476 \\
\hline
\end{tabular}

The four identified components explain $65.476 \%$ of the variance observed in the data. This are changes in the data that can be accounted for by the factor structure. Each of the items were grouped under the four identified components or groups of factors using the highest observed loading. The groups were identified as agent related discrimination; landlord related discrimination; tenant in occupation related discrimination; and prospective tenant related discrimination.

\section{Conclusion}

Housing is a necessity and therefore studies on rental housing are of social importance and should be economically interesting to all stakeholders. The responsibility for uncovering discrimination in rental housing falls on researchers and all stakeholders in the rental market. In particular, to protect the rights of the minority, there is need for studies on how to detect rental discrimination in Nigerian rental housing sector and why it arises.

The study however identified four major categories of discriminatory practices in the rental housing as agent related discrimination; landlord related discrimination; tenant in occupation related discrimination; and prospective tenant related discrimination. The study recommends for more protection in the private rental sector in Nigeria and the need for the implementation of rental policies for tenants to seek justice in cases of rental discrimination. The benefits of this study could reduce the occurrence of discrimination in rental housing, ensure better housing delivery in Nigeria, and these could translate into a better society.

\section{References:}

Ahmed, A. and Hammarstedt, M., (2007). "Discrimination in the housing market - a field experiment on the internet," CAFO Working Papers 2007:1, Centre for Labour Market Policy Research (CAFO), School of Business and Economics, Linnaeus University.

Beatty, T. K. M., and Sommervoll, D. E., (2008). Discrimination in Europe: Evidence from the Rental Market, Discussion Papers No. 547, Statistics Norway, Research Department, June 2008

Bosch, M., Carnero, M. A., and Farre, L., (2009). The Real Life Dictionary of the Law, http://dictionary.law.com (last visited April. 15, 2011). 
Choi, S. J., Ondrich, J., and Yinger, J. (2005). "Do Rental Agents Discriminate Against Minority Customers? Evidence from the 2000 Housing Discrimination Study", Journal of Housing Economics, Vol. 14, pp. 1-26.

Dymski, G. A., (2001). Is Discrimination Disappearing? Racial Differentials in Access to Credit, 1992 - 1998. International Journal and Social Economics, Vol. 28, pp. 1025-1045.

Galster, G. C. (1990). Racial Steering by Real Estate Agents: Mechanisms and Motives, Review of Black Political Economy 19 (Summer): 39-63

Hall, K.L. (2005). "Housing Discrimination." The Oxford Companion to the Supreme Court of the United States. 2005. Retrieved March 21, 2011 from Encyclopedia.com: http://www.encyclopedia.com/doc/1O184HousingDiscrimination.html

Hulchanski J. D. (1994). Discrimination in Ontario's Rental Housing Market: The Role of Minimum Income Criteria, PhD, MCIP, Professor, Housing Policy and Community Development Faculty of Social Work, University of Toronto Prepared for the Ontario Human Rights Commission

Marsden, M., (1994). Board Issues Fair Lending Policy Statement, Financial Update, Vol. 7(1-2): 1-3.

Ondrich, J., Ross, S., and Yinger, J. (2001). Now You See It, Now You Don't: Why Do Real Estate Agents withhold houses from Black Customers? Working paper No. 24, Syracuse University, Center for Policy Research.Rev. June

Roychoudhury, C., and Goodman, A. C., (1996). "Evidence of Racial Discrimination in Different Dimensions of Housing Search", Real Estate Economics, Summer, Vol. 24, pp.161-178.

Yinger, J. (1986). Measuring Discrimination with Fair Housing Audits: Caught in the Act, American Economic Review 76 (December): 881-93

Yinger, J. (1998). Housing Discrimination is Still Worth Worrying about, Housing Policy Debate 9(4): 893-927

Zalesne, D., (1997). The Intersection of Socio-Economic Class and Gender in Hostile Housing Environment Claims Under Title Viii: Who is the Reasonable Person? CUNY School of Law Boston College Law Review, Vol. 38, p. 861, 1997 